\title{
A pituitary tumour presenting with rhinolalia and galactorrhoea
}

\author{
Charles Anwuzia-Iwegbu, Scott Akker
}

Department of Specialist Endocrine, Barts \& The Royal London, London, UK

\section{Correspondence to} Dr Charles Anwuzia-Iwegbu, c.anwuzia-iwegbu@uea.ac.uk

\section{DESCRIPTION}

A 37-year-old lady presented to her general practitioner (GP) with a history of intermittent galactorrhoea and amenorrhoea. She reported intermittent galactorrhoea to have been present following her last pregnancy 4 years previously. Earlier in the year she had been seen and treated for nasal symptoms which had caused hypernasal speech (rhinolalia). For this she was receiving fluticasone nasal spray. The patient had a background of hypertension, well controlled on amiloride $10 \mathrm{mg}$ once daily and lisinopril $20 \mathrm{mg}$ once daily. There was no relevant family history.

Following an episode of menorrhagia, the patient had presented to her GP and routine blood tests were performed which included a serum prolactin of $3428 \mathrm{mu} / \mathrm{l}(25-629 \mathrm{u} / \mathrm{l})$. The GP requested an MRI scan which revealed a very large $(4.4 \times 4.6 \times 2.7 \mathrm{~cm})$ and extensive macroadenoma involving the central skull base (figure 1). There was significant suprasellar extension compressing the chiasm. Although there was no convincing lateral extension into the cavernous sinuses, there was filling of the sphenoid air sinus with the tumour and extension into both the left and right nasal cavities. On the left the extension was significant with displacement of the turbinates.

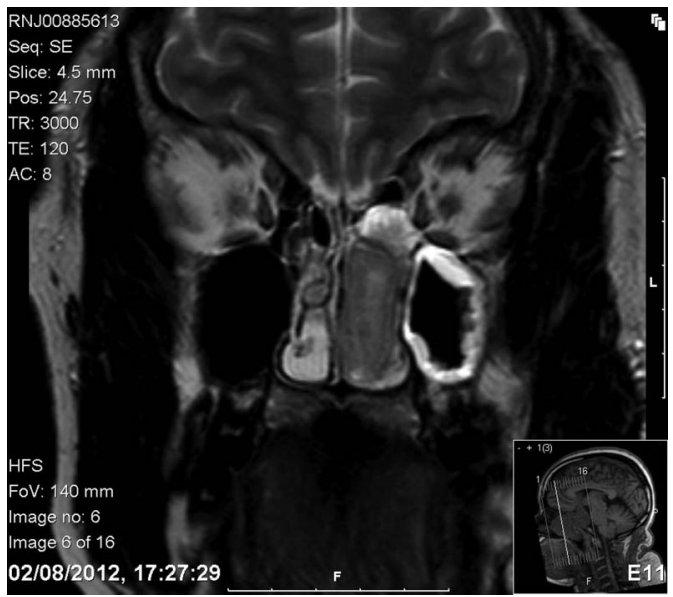

Figure 1 Demonstration of a large and extensive macroadenoma involving the central skull base. There is also a significant suprasellar extension to compress and stretch the chiasm but there was no convincing lateral extension into the cavernous sinuses. There is much involvement of the central sphenoid with the tumour seen filling the sphenoid air sinus and extending forward into the posterior ethmoids with a significant component in the left middle and inferior nasal cavities displacing the turbinates. There is much more limited involvement of the posterior aspect of the right nasal cavity.

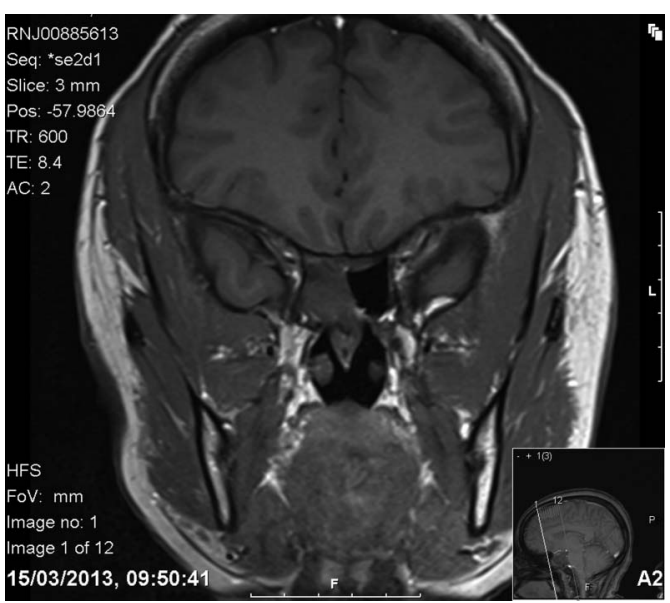

Figure 2 The pituitary macroadenoma has been removed.

She was referred to our centre. All the other endocrinology was within normal limits. The prolactin level was confirmed with dilution to exclude a hook effect and trial of low-dose cabergoline was given which suppressed the prolactin to $23 \mathrm{mu} / \mathrm{l}$ in keeping with disinhibition. Although felt to be in keeping with a tumour originating from the pituitary, because of the very unusual appearance of this tumour, the nasal component was removed first (figure 2). This confirmed a null cell pituitary adenoma with a Ki67 index $<1 \% .{ }^{1}$ She subsequently underwent trans-sphenoidal surgery with clearance of the remaining tumour and no postoperative complications.

\section{Learning points}

- In a patient with inappropriate galactorrhoeacheck the prolactin levels. ${ }^{1}$

- Consider other differential diagnosis for causes of hyperprolactinoma, for example, excluding medication use, renal failure, hypothyroidism and parasellar tumours causing compression or displacement of the pituitary stalk in patients with symptomatic non-physiological hyperprolactinaemia. ${ }^{2}$

- Head MRI scanning is essential.

- Trial of cabergoline therapy may help shrink tumour avoiding surgical intervention.

Acknowledgements Many thanks to the Specialist Endocrinology Team Dr H Chahal, Dr E Panteliou, Dr S Hussain, Dr A Mian and Mr Sabin (neurosurgeon). 
Contributors CA-I examined the patient and drafted the article. SA chooses management options for the patient and proofread the article.

Competing interests None.

Patient consent Obtained.

Provenance and peer review Not commissioned; externally peer reviewed.

\section{REFERENCES}

1 Melmed S, Kleinberg D. Pituitary masses and tumours. In: Kronenberg HM, Melmed S, Polonsky KS, Larsen PR, eds. Williams textbook of endocrinology. Chap 9, 12th edn. Philadelphia, PA: Saunders Elsevier, 2011.

2 Melmed S, Casanueva FF, Hoffman AR, et al. Diagnosis \& Treatment of Hyperprolactinemia: An Endocrine Society Clinical Practice Guideline. The Endocrine Society, 2011. http://www.endo-society.org/guidelines/final/upload/ Diagnosis-Treatment-of-Hyperprolactinemia.pdf (accessed 9 Mar 2013).

Copyright 2013 BMJ Publishing Group. All rights reserved. For permission to reuse any of this content visit http://group.bmj.com/group/rights-licensing/permissions.

BMJ Case Report Fellows may re-use this article for personal use and teaching without any further permission.

Become a Fellow of BMJ Case Reports today and you can:

- Submit as many cases as you like

- Enjoy fast sympathetic peer review and rapid publication of accepted articles

- Access all the published articles

- Re-use any of the published material for personal use and teaching without further permission

For information on Institutional Fellowships contact consortiasales@bmjgroup.com

Visit casereports.bmj.com for more articles like this and to become a Fellow 